\title{
Analysis of the family's communication pattern and the benefits of mother school program for building a harmonious family
}

\author{
Firdanianty Pramono \\ Communication Studies Program, \\ Candradimuka Academy of Social and Political Sciences \\ firdanianty@stisipolcandradimuka.ac.id
}

Article History: Received 2020-02-11, Revised 2020-07-20, Published 2020-07-30

\begin{abstract}
Positive communication plays an important role in building a harmonious family. The objectives of this research were to: 1) Identify the characteristics of Mother School participants in 3 urban villages in Bogor; 2) Classifying family communication patterns of participants in Mother Schools based on low, moderate, and high categories; and 3) Analyze the benefits of Mother School program. The study was conducted with quantitative and qualitative approaches. The respondents were 84 people from the villages of Ciluar, Ciparigi, and Kedung Halang. Quantitative data were processed descriptively and analyzed using the Anova one way test. The qualitative data were obtained from the writing of participants in Ciluar village as many as 30 people, and then analyzed to find out the benefits of Mother School program. The results showed that the majority $(84.62 \%)$ of respondents stated strongly agree that family togetherness is everything and 71.79 percent felt very close to their husband and children. By region, the participants of Mother School in Ciparigi village whose family communication was in high category had the highest percentage (60.71\%). Maternal education level is considered to be a key factor in family communication in Ciparigi Mother School participants, better than 2 other villages. Qualitative analysis showed that participants feel the benefits of Mother School which can increase knowledge and understanding of how to care their children and build a harmonious family. This research is expected to be input for the Government of Bogor to further improve the quality of family resources.
\end{abstract}

Komunikasi yang positif berperan penting dalam membangun keluarga harmonis. Penelitian ini bertujuan untuk: 1) Mengidentifikasi karakteristik peserta Sekolah Ibu di 3 kelurahan Kota Bogor; 2) Mengelompokkan pola komunikasi keluarga peserta Sekolah Ibu berdasarkan kategori rendah, sedang, dan tinggi; dan 3) Menganalisis manfaat program Sekolah Ibu. Penelitian dilakukan dengan pendekatan kuantitatif dan kualitatif. Responden yang disurvei berjumlah 84 orang berasal dari kelurahan Ciluar, Ciparigi, dan Kedung Halang. Data kuantitatif diolah secara deskriptif dan dianalisis dengan uji one way Anova. Adapun data kualitatif diperoleh dari tulisan peserta di kelurahan Ciluar 
sebanyak 30 orang, kemudian dianalisis untuk mengetahui manfaat program Sekolah Ibu. Hasil penelitian menunjukkan, sebagian besar (84.62\%) responden menyatakan sangat setuju bahwa kebersamaan keluarga adalah segalanya dan 71.79 persen merasa sangat dekat dengan suami dan anak-anaknya. Berdasarkan wilayah, peserta Sekolah Ibu di kelurahan Ciparigi yang komunikasi keluarganya masuk kategori tinggi memiliki persentase terbanyak (60.71\%). Tingkat pendidikan ibu diduga merupakan faktor utama komunikasi keluarga peserta Sekolah Ibu di Ciparigi lebih baik dibandingkan 2 kelurahan lain. Analisis kualitatif memperlihatkan, peserta merasakan manfaat Sekolah Ibu yang dapat menambah pengetahuan dan pemahaman tentang cara mengasuh anak dan membangun keluarga harmonis. Penelitian ini diharapkan menjadi masukan bagi Pemerintah Kota Bogor untuk lebih meningkatkan kualitas sumber daya keluarga.

Keywords: family communication patterns, benefits, mother school, Bogor

\section{INTRODUCTION}

Having a harmonious family is everyone's dream. In a harmonious family, each family member interacts and communicates positively so that conflict can be avoided. A conducive family environment also supports the child's growth and development process. Grych research results (Santrock, 2007) revealed, parents with happy marriages tend to be more sensitive, responsive, warm, and affective towards their children and adolescents. The researchers also found that marital satisfaction is often associated with good parenting. Marital relationship is one of the important supporting factors in childcare. When parents report more intimate marital relationship and good communication, they tend to be more affective to their children and adolescents.

Conversely, poor communication and interaction between father and mother can lead to disharmony in the family which results in divorce. Amalia et al. (2017) concluded that disharmony is one of the causes of divorce. Indonesia is one of the countries with high divorce rate. Divorce cases in Indonesia, as described in Statistics Indonesia 2018, during the 2015-2017 period experienced an increasing trend. The case of divorce that occurred in Indonesia throughout 2017 reached 374,516 cases. That number increased compared to 2016 which recorded 365,654 cases and in 2015 with 353,843 cases.

Geographically, the highest number of divorces in 2017 occurred in East Java Province, with 84,475 cases, followed by West Java (79,047 cases) and Central Java (69,857 cases). The high divorce rate is due to many factors ranging from economic problems, acts of domestic violence, communication issues, and infidelity. Data from Cibinong Religious Court class $1 \mathrm{~A}$ in January-August 2018 period stated that the number of divorce (talak) cases submitted by men was 756 cases, while the number of divorce (gugat) claims by women reached 2,560 cases. In 2017 , the number of women who filed for divorce was 3,310 people, far exceeding the case of divorce filed by men, which was 981 people. This shows that divorce cases are now more likely to be submitted by women than men. Some reasons for women suing for divorce are the influence of activities on social media, economic problems, domestic violence, and infidelity (Indopos, 2018).

One of the main causes in lack of family harmony is family communication issues. Research by Goldberg et al. (2014) showed a significant correlation between mutual support between couples and children's behavior. Children, who come from harmoniousand mutually supportive parents, exhibit a low level of behavior problems. The results of Metia's (2017) study of mothers who work as employees in Percut Sei Tuan District, North Sumatra, also showed that therewas a positiveand significant correlation between interpersonal communication and family harmony. Metia (2017) concluded that interpersonal communication had an influence of 86.8 percent on family harmony.

Some previous studies in Indonesia related to aspects of family communication and child development, including Hamzah 
(2002) concerning the effect of family communication on juvenile delinquency in Karang Besuki, Malang, with quantitative descriptive methods. The findings showed that continuously-practiced family communication can reduce the level of juveniledelinquency. Research by Puspitawati (2006) on the influence of family, friends and school factors on the delinquency of students in senior high schools in Bogor City showed that adolescents with high attachment to their peers have the opportunity to commit criminal delinquency 1.157 times greater than adolescents with low attachment to peers. Puspitawati (2006) revealed the importance of the role of parents in carrying out the function of adolescent socialization and education. It is known that aggressive behavior and high juvenile delinquency is directly affected by low communication between parents and teens, and high friendship. E Silva et al. (2016) strengthen Puspitawati (2006) that the quality of a good relationship between adolescents and mothers is a protective factor against early sexual initiation for girls.

In addition, research by Pramono et al. (2016) explained that adolescentfamily communication patterns affected on adolescent learning achievement and emotional intelligence. The better communication between adolescents with their parents, the better academic achievement and emotional intelligence adolescents can be obtained. Some of the results of these studies indicate that positive communication is one of the factors supporting the success of families in realizing a harmonious family and minimizing the problem of juvenile delinquency. Muhwezy et al. (2015) emphasized that the warmth of parents and the acceptance of children is the basis of healthy family communication.

One of the efforts made by the Government of Bogor City to lower divorce rates and strengthening family resilience was launching a Mother School (Sekolah Ibu) program. The establishment of Mother School departed from the social phenomena occurring in society today, which are characterized by high divorce rates, domestic violence, juvenile delinquency (student fights), the use and distribution of drugs and free sex, which is very alarming. Mother School has been held simultaneously in 68 villages throughout Bogor City since July 2018. Schooling process has been held in village halls in Bogor City twice a week every Monday and Thursday at 1 until 3 o'clock in 20 sessions (10 weeks). Within a year, Mother School has been held in 2 batches.

Participants in Mother School are married women with children aged 0- 12 years, maximum age for the mother is 45 years and guided by more than 120 faculty volunteers from various backgrounds. Each participant is required to attend learning activities in the village and receive material that has been compiled by the PKK (Family Welfare Development Program) Mobilization Team of Bogor City. Until now, Mother School Program has graduated 8.ooo participants and it has entered the 3rd year of its implementation.

Mother School aims to increase mothers' knowledge as a first and foremost educator in the family, and strengthen the family resilience. The program is spearheaded by PKK (Family Welfare Development Program) Mobilization Team of Bogor City and had the support of the City Government and Regional House of Representatives (DPRD) of Bogor. Since the start of the program, there has been no scientific study of Mother School. Therefore, this research is considered important because Mother School program is relatively new in Bogor, so it is important to know the benefits for participants.

Departing from this background, the author wants to know the success of Mother School program. The objectives of this research were to: 1) Identify the characteristics of MotherSchool participants in threevillages in Bogor City (Ciluar, Ciparigi, and Kedung Halang) ; 2) Classify family communication patterns of participants in Mother Schools based on low, moderate, and high categories; and 3) Analyze the benefits of Mother School program through qualitative approach . 


\section{LITERATURE REVIEW}

The family is the first social environment that introduces love, religious morals, social culture, and so on to children (KPPPA, 2016). Family is seen as a primary group consisting of two or more people who have a network of interpersonal interactions, blood relations, marital relations, and adoption (Puspitawati, 2012). Family is also valued as a unity of interactions and communications that can be seen from the involvement of all people in playing their roles, either as husband and wife, parents and children, as well as children and their siblings. From the process of interactions and communications, family is expected to play an important role in maintaining a shared culture, as stated in Law no. 1 of 1974 (Wiratri, 2018).

Metia (2017) defines family harmony as a form of harmony between each family member as indicated by the creation of a climate of mutual respect, mutual acceptance, mutual understanding, and mutual love, so that each family member can experience physical and spiritual wellbeing. Family harmony expressed by aspects of the proposed Gunarsa (2004), namely, the existence of love, mutual understanding, and communication that exists among family members, and good cooperation between family members. Sari and Puspitawati (2017) added that family harmony can be created if the functions in the family can be run well and there is a balance in the family system.

Koerner and Fitzpatrick (2004) classified families according to three points of view, namely, structural, functional (psychosocial) and transactional definitions.

- Structural definition. The family is defined based on the presence or absence of family members, such as parents, children and other relatives. This definition focuses on who becomes part of the family. From this perspective, it can bring up the understanding of family as the origin (family of origin), family as a means of childbearing (family of procreation), and as batih family (nuclear family).
- Functional (psychosocial) definition. Family is defined with an emphasis on fulfilling psychosocial tasks and functions. These functions include care, outreach to children, emotional and material support, and fulfillment of certain roles. This definition focuses on the tasks performed by the family.

- Transactional definition. The family is defined as a group that develops intimacy through behaviors that give rise to a sense of identity as a family (family identity), in the form of emotional bonds, historical experiences, and future goals. This definition focuses on how the family carries out its functions.

From a psychological point of view, the family is influenced by the interaction between family members and their ability to adjust in the midst of change, which in turn affects the existence and function of the family. Interactions between family members often encounter obstacles if there is no understanding of the characteristics of development in family members (Setiono, 2011).

Every family needs communication to negotiate goals, instill values, maintain regulation, and balance in the family. To find the destination, family members provide input, while the parents introduce rules and routines (Wilson et al., 1995). Socha (2009) suggests there are two approaches to understanding family communication. First, family communication plays a role in increasing positive family input (for example, increasing affection, creativity, hope, and happiness). Second, family communication creates conditions that facilitate the development of family potential, or uses communication to create optimal conditions for HR growth and development.

Family communication is also directed to provide motivation and support to children. In this case, parents create a home as a "learning environment", which teaches the values of goodness, morals, and ethics. Parents are required to behave like 
teachers. That means parents know their child's problems and assignments at school, and can evaluate their child's development (Rahmawati \& Gazali, 2018).

On the other hand, family communication is also developed to educate family members to become human beings with character. According to Megawangi (2007), good character is characterized by being honest, respectful and polite, having empathy, tolerance, and listening to others. Rahmah's research (2018) shows that good communication patterns are needed to shape a child's personality. Therefore, a dialogical approach that is associated with a participatory paradigm is the right choice to create a constructive (family) environment (Mefalopulos, 2008).

The pattern of family communication is rooted in creating relationships between families, which in it shows a number of processes such as family talks, family rituals, parents support for children, and understanding among family members. Someone can learn how to love, provide comfort, how to support, even disputes through family relationships. Communication is needed by every family to negotiate goals, instill values, and maintain regulation and balance in the family. To find common goals, family members provide input and monitor results. Parents introduce procedures, rules, and routines to achieve a family goal (Wilson et al., 1995). This explanation reinforces the definition of communication put forward by West and Turner (2011), the social process in which individuals use symbols to create and interpret meanings in their environment.

Every family member needs to master the correct way of communication, so as to avoid miscommunication or communication errors. Communication error on family members could have happened if the messenger was not clearly presented, with improper delivery method, lacking of consideration when to say something, and lacking of consideration to the condition of the other party. Conversely, the recipient of the message can also cause communication errors. This happens when the recipient of the message was not open about the ideas of others, already had a certain view, and did not consider the condition or situation of the messenger (Setiono, 2011).

In realizing a harmonious family does not mean free from conflict. Building a harmonious family is characterized by constructive attitudes and ways in conflict resolution. Uniformity of the system and continuity of communication will provide a sense of security and regularity in the family, so as to create a harmonious family (Nancy, 2013). It is important to remember that communication involves the sense of listening, the availability to understand, mutual respect, and emotions. The findings of Runcan et al. (2012) concerning parent and child communication showed that communication is very important in parentchild interaction, especially if parents want to pass on important values in life to their children in the present and especially in the future.

\section{METHODS}

This research used multiple methods, which combines quantitative and qualitative approaches. The quantitative approach was conducted through a survey method with a cross sectional study design. Quantitative data was taken at the 16 th session of Mother School Program (13 September 2018). The number of respondents was 84 people from three villages, namely Ciluar (30 people), Ciparigi (3o people), and Kedung Halang (24 people). The three villages were chosen by purposive sampling technique.

To get quantitative data, Mother School participants in three villages were given a set of questionnaires containing 20 questions with four answer choices: strongly disagree, disagree, agree, and strongly agree. Questions asked about the communication between wife and husband, and communication between mother and child. Questions and statements related to the husband, for example, my husband is a good listener to the whole family. Other questions and statements related to the 
husband, for example, when my husband is angry, he easily shows his anger and expresses harsh words to me. Meanwhile, questions and statements related to mother and child communication, among others, my child can easily tell me all the things he/she felt and he/she experienced to me. In addition, there are also questions to examine the Mother-Father-Child relationship, such as: husband, children and I are easily discussing everything we experienced together.

After the data was collected, only 78 respondents met the criteria of an intact family. Data from 6 respondents cannot be used because their status is no longer married. Data were analyzed descriptively and tested with one way ANOVA analysis using the SPSS program.

In addition to the quantitative approach, a qualitative approach is also used to obtain important information that is not revealed in quantitative measurements. The qualitative approach in this study refers to the writings of 30 school participants in the Ciluar subdistrict, especially those relating to aspects of communication and family harmony. The 30 participants wrote down their feelings related to husband-wife, motherchild, and mother-teen communication. From the results of the qualitative analysis, it is then seen the benefits felt by the participants of Mother School towards family harmony.

\section{RESULTS AND DISCUSSION}

Characteristics of Mother School Participants

Respondents in this study were the participants of Mother School who came from threevillages in the city of Bogor, namely the villages of Ciluar, Ciparigi, and Kedung Halang as many as 84 people. However, the answer of 6 respondents cannot be processed further because they were no longer married. Thus, respondents who were considered to meet the criteria of an intact family were 78 people. Most participants came from the villages of Ciluar and Ciparigi, each of them was 28 people (Table 1 ).
Table 1: Distribution of participants by region of origin (percent)

\begin{tabular}{|l|l|l|}
\hline Region of Origin & $\mathbf{n}$ & \% \\
\hline Kedung Halang Village & 22 & 28.2 \\
\hline Ciluar Village & 28 & 35.9 \\
\hline Ciparigi Village & 28 & 35.9 \\
\hline Total & 78 & 100.0 \\
\hline
\end{tabular}

The number of participants in Mother School in the three villages ranged from 22 - 55 years with an average age of 36.49 years. One participant was recorded as having an age that exceeded the requirements for joining the program (55 years), but was still permitted because she had school-age children. The majority of participants in this study was young adults or in the productive age category. Participants in the middle adulthood category were 21.8 percent. There were no elderly participants in this study. Mother School participants husband age ranged from 28-61 years with an average age of 41.5 years. All of the husbands were young adults (50.0 \%) and middle-aged adults (48.7\%). Only 1, 3 percent of husbands were young elderly. The youngest age of the first child is one year old and the oldest was 36 years old with the average age of the child was 14.72 years. Most respondents had their first child who was in their late teens (35.9\%), followed by early teens (30.8\%). Only a few of the first born children were in early adulthood (3.8\%). Mother School participants have at least one child and five children at most with average number of children as many as two children. More than half of the participants have two children at most (69.2\%) and small proportion of them have as many children as 3- 5 people (30.8\%).

Viewed from the level of education, it varies from not attending school, failed to graduate from elementary school, graduated from elementary school, graduated from junior high school, graduated from high school, and graduated from Diploma 1 / Diploma 2 / Diploma 3 and some of them have a bachelor's degree. The highest percentage of maternal education was high school graduation (43.6\%). This shows that the level 
of education is not good enough. A total of 5.1 percent of mothers graduated from Diploma 1 - Diploma 3 and 2.6 percent of mothers have undergraduate degree. Likewise, the husband's education was spread across various levels of education ranging from failed to graduate from elementary school, graduated from elementary school, failed to graduate from junior high, graduated from junior high, graduated from high school, graduated from D1 / D2 / D3 have bachelor's degree, and master's degree. The biggest percentage of husband's education level was high school graduation (55.1\%). As many as 5.1 percent of husbands have undergraduate level and as many as 1.3 percent of husbands have graduate (master's degree or higher) level of education.

Based on the types of occupations, the largest percentage was housewives $(89,7 \%)$ and the rest were working mothers. The types of occupations that mothers have were household assistants (3.8\%), teachers (3.8\%), traders $(1.3 \%)$, and employees $(1,3 \%)$. The biggest percentage of husband's occupation was labor (35.9\%). The next largest types of husband's occupations were employee (33.3 $\%)$ and self- employed/entrepreneur (16.7\%).

\section{Family Communication Patterns}

Judging from the survey responses, the majority $(84.62 \%)$ of respondents stated strongly agree that family togetherness is everything and 71.79 percent felt very close to their husband and children. More than 60 percent of respondents agreed that their children had told all their experiences and feelings to their father. Almostall respondents were satisfied with the way the family solved the problem together $(61.54 \%$ agreed and $39.90 \%$ strongly agreed). Most respondents (74.36\%) agreed that their children were good listeners and only 8.97 percent answered otherwise. Most respondents also felt satisfied with the way they communicated with their husband and children. However, there were two respondents (2.56\%) who strongly disagreed that their husband was a good listener. In other words, as many as two participants admitted that her husband was not a good listener.

The results showed the communication index scores of participants ranged between 33.33 and 98.33 with an average index score of 77.74 . More than half of the participants had high level of communication (52.6\%) and almost half had moderate level of communication (47.4\%) (Table 2).

Table 2: Distribution of family communication based on low, moderate and high categories

\begin{tabular}{|l|c|c||}
\hline Category & $\mathbf{n}$ & \% \\
\hline Low $(<50)$ & 1 & 1.3 \\
\hline Moderate (50-75) & 36 & 47.4 \\
\hline Height (> 75) & 41 & 52.6 \\
\hline Total & 78 & 100.0 \\
\hline Average (Score 0-100) & \multicolumn{2}{|c||}{$77.74 \pm 10.80$} \\
\hline Minimum (Score 0-100) & \multicolumn{2}{|c|}{33.33} \\
\hline Maximum (Score 0-100) & \multicolumn{2}{|c|}{98.33} \\
\hline
\end{tabular}

Test results using the analysis of one-way ANOVA (Table 3 ) showed that participants School Mother in different regions show different communication index score anyway . Different test results showed that participants who lived in the Ciparigi region had higher communication scores than mothers who lived in the Kedung Halang area $(\mathrm{p}=0.048)$ and Ciluar $(\mathrm{p}=0.011)$.

Table 3 : Differences in means and $p$ - values of family communication between regions

\begin{tabular}{|c|c|c|c|c|c|}
\hline \multirow{2}{*}{ No } & \multirow{2}{*}{ Region 1} & \multirow{2}{*}{ Region 2} & \multicolumn{2}{|c|}{$\begin{array}{c}\text { Average Index } \\
\text { Score (0-100) }\end{array}$} & \multirow[b]{2}{*}{$p$-value } \\
\hline & & & $\begin{array}{l}\text { Region } 1 \\
\text { Average }\end{array}$ & $\begin{array}{l}\text { Region } 2 \\
\text { Average }\end{array}$ & \\
\hline \multirow[t]{2}{*}{1} & $\begin{array}{l}\text { Kedung } \\
\text { Halang }\end{array}$ & Ciluar & 76.06 & 74.76 & 0.663 \\
\hline & & Ciparigi & & 82.02 & $0.048 *$ \\
\hline \multirow[t]{2}{*}{2} & Ciluar & $\begin{array}{l}\text { Kedung } \\
\text { Halang }\end{array}$ & 74.76 & 76.06 & 0.663 \\
\hline & & Ciparigi & & 82.02 & $0.011^{*}$ \\
\hline \multirow[t]{2}{*}{3} & Ciparigi & $\begin{array}{l}\text { Kedung } \\
\text { Halang }\end{array}$ & 82.02 & 76.06 & $0.048^{*}$ \\
\hline & & Ciluar & & 74.76 & $0.011 *$ \\
\hline No & tes: $* *$ & ignificar & $\begin{array}{l}\text { at } \leq 0.01 \\
0.05\end{array}$ & ; * signif & ant at \\
\hline
\end{tabular}


is the highest percentage $(60.71 \%)$, while the Ciluar kelurahan is 32.14 percent and Kedung Halang is 18.18 percent. Compared to Ciluar and Kedung Halang, participants in Mother School in Ciparigi village whose family communication was in the low category were also at least (3.58\%), followed by Kedung Halang (4.55\%) and Ciluar (7.15\%) (Diagram 1).

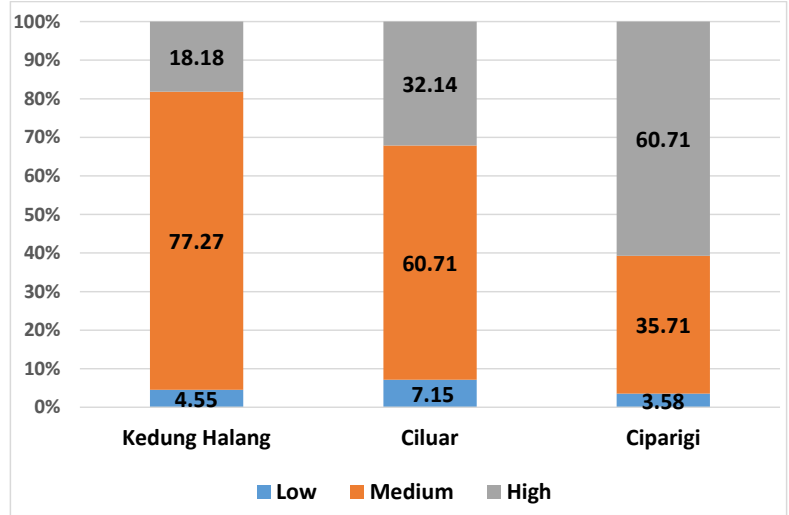

Diagram 1. Percentage distribution of family communication by region

Based on these findings, the authors suspect that the level of education of the mother is a major factor why the communication of the participants' families in Mother School in Ciparigi is better than the other two. Diagram 2 shows that Mother School participants from Ciparigi have a higher level of education than Ciluar and Kedung Halang. Most (85.72\%) participants of Mother School from Ciparigi kelurahan had a moderate level of education (graduating junior high and high school) and only 3.57 percent entered the low category (only up to elementary school). Song and Hattie (1984) argue that the atmosphere of the home is influenced by the level of parental education. A Charya and Joshi (2009) reinforce that mother's education level is positively related to children's academic achievement. Meanwhile, Asilah and Hastuti's research (2014) concluded that family income, mother's last education, and family size were significantly and negatively related to maternal stress levels. This shows, the greater the household income per month, the higher the mother's last education, and the greater the number of family members, the mother's stress level tends to be lighter. A happy mother is expected to be able to build a harmonious family and take good care of her children.



Diagram 2. Percentage of maternal education distribution by region

In addition to mother's education level, the number of children owned is also related to the high and low level of family communication. Based on data from the average number of children owned by Mother School participants per region, the results are as follows: the average number in Ciparigi was 2.0 children; Kedung Halang was 2.09 children; and Ciluar with 2.61 children. Thus, the number of children owned by Mother School participants in Ciparigi was less than the other two villages. Although the number of children owned by Mother School participants in Ciparigi was not significantly different from that in Kedung Halang, the percentage remains smaller than Kedung Halang. This is thought to be positively related to family communication patterns. But to arrive at these conclusions, the writer needs further evident supported by the number of respondents.

Communication and interaction within the family is part of children socialization process carried out by parents. There are at least three things that must be considered in this socialization process, i.e, socialized behavior pattern, participating agents in socialization process (parents, children, friends, teachers, television programs), techniques and implementations of the socialization process (Puspitawati, 2012). Through communication and interaction in the family, parents and children can strengthen interpersonal relationships that may prevent the children from associating 
with deviant peers.

\section{Benefits of Mother School Program}

Qualitative data in this study were obtained from the written opinions of 30 participants of Mother School program in Ciluar. From the first until the 19th session, teachers gave homework to Mother School participants according to the presented material. From 19 modules that are provided to the participants of School Mother, there are three modules that focus on aspects of family communication, i.e: Effective Communication on Husband and Wife (5th module), Parenting and Communication with Children (15th module), and Building Communication with Adolescent (16th module).

At the first session, the teacher asked participants, "What is the role of women in the family?" The majority of participants wrote their roles only around domestic tasks such as washing, cooking, cleaning the house, managing daily expenses, and taking care of children and husband. Only a few participants mentioned their role as teacher/educator for their children, as a partner for their husbands, and help succeed their husbands' career.

Accordingly, Segrin and Jeanne (2005) argued that family has usual activities such as the sharing out roles, making decision to buy something, whether or not members of the family should do something and so on. This depends on the system or regulations that apply to each family. Rules in the family are usually based on agreements, both explicitly conveyed through conversation or implicitly (not through conversation). Participants' answers about their role in the family which focused more on domestic tasks, allegedly related to the level of education and patriarchal culture that was deeply embedded in the family environment. After attending Mother School program, the participants realized that their role in the family was not just about carrying out domestic tasks. More than that, participants were invited to understand themselves and discover their potential to be optimized in order to improve the quality and welfare of the family.

When studying the Effective Communication Module on Husband and Wife (5th session), the homework given was to write down the experiences of participants in expressing love for their husbands. When receiving this assignment, the participants initially objected because they claimed to be unfamiliar with that. "I haven't told my husband that I love him for so long" said one participant. Nevertheless, the participants continue to do the task and write the results well. The following are the outpouring of some participants when expressing the language of love to their husband:

"After one week I did not see my husband, last Sunday night my husband came home. After he had eaten, we both chatted and then I said, 'when you left for work, I always missed you.' My husband smiled, and then he answered, 'Honey, I felt the same way every day, longed for your cooking and your babble. Every day, every time always missed you.' (MS, 30 years old)

"I demonstrated the words of affection to my husband by saying, 'Honey, I still love you. Do you still love me too?' Husband answered, 'Of course, I love you' He said with a smile, 'You're overthinking it. I say I love you every day, don't I?' (NJ, 39 years old)

"I seduced my husband; he just stared for 5 minutes and blushed because it was strange that his wife suddenly seduced him." (FY, 27 years old)

"Last Sunday we had a family event and at the same time attended a wedding invitation from my husband's officemate. We decided to wear clothes with matching colors. After my husband was ready, I said, 'Gosh, you are so handsome, you are almost look like a Korean star. "He immediately smiled while hugging me." (DD, 39 years old)

"When I said, 'I love you', my husband immediately embraced, touched, and kissed my cheek while pampering me. At that moment I blushed." (SK, 30 years old) 
Related to the material of Parenting and Communication with Children (15th session), the instructor asked participants to write down their difficulties when dealing with children with unmanageable behavior. Following are the experiences from some of the participants:

"I have a difficult child. If I was upset, I would be very angry. My other children, when I told them to go to the stall, always ask for money and their wishes must be obeyed. Sometimes I don't know how to deal with my children whose characters are different. But Alhamdulillah, Mother School program has many positive effects on my patience and awareness, so that I can understand the character of my children and gradually overcome them." (SK, 30 years old)

"Deal with children who like to whine and ask for toys must take extra patient. Proven in my child who likes to cry and whine if asking for something. He kept crying and whining, but I didn't respond. 'Anyway I will not buy it', then I slowly advised him. 'Honey, the price of the toy is expensive ... So, your father and I need to save money to buy the toy. Now you have to save the money first. Later when we have saved a lot, we buy the toys. "In a low tone my son finally relented.” (RH, 36 years old)

"My second child doesn't like to eat. He must be persuaded first with 'I'll buy ice cream' then he will eat. Otherwise, my child will not eat, he is able to resist hunger. Alhamdulillah, with the existence of Mother School, I am able to introspect and be patient, which I always remeber, because that is the key." (MR, 38 years old)

"I used to feel inconvenient and difficult to control my child. If he asks for something, it must be bought that exact same day. Since I attended Mother School, I have come to know and understand more about how to educate children and communicate well and many lessons on how to deal with super active and inquisitive children. Alhamdulillah, my child is now a sweet, obedient child, and he is not cranky if he wants something." (NS, 30 years)

At the 16th session, the participants increasingly understood their roles as mother and wife. This can be seen from the answers given when filling out the Family Communication questionnaire. In the Building Communication with Teen module, the teacher asked moms to take their teenage sons and daughters to spend some time alone. Some participants shared their experiences below:

"On Sunday my son and I left. We went to ride bikes while exercising. We walked on the streets of the village. I have no money to travel to the city; so I chose the free one. Then we chatted. My son talked about playing futsal, fishing, and school. My son said, 'The lessons at school now are harder, I get tired quickly'. 'Unexpectedly, you invited me to take a walk; it is fun to see the view of the garden, the rice fields, and farmers. So it is more fresh and comfortable. It is fun traveling with you."'(NM, 35 years old)

"My experience of being alone with my first child was very fun and happy because my child is an easygoing person. While waiting for food orders, I chatted with my child. My child tells a problem with friends who have different characters. My child told me there was a female friend who was close to him but only as friend. I listened to him intenly. I provided feedback to my child that he should be careful in making friends. He may allowed to be close to women, but only as friends. Hopefully my child and I can have a better parent-child relationship, and I also hope I can be a good mother and wife. "(LM, 38 years old)

"I went with my 15-year-old second child. I was riding on motorcycle with him. Then I took her to eat chicken noodles. While eating, she told me about her friend who was scolded by the teacher because she likes to over makeup. I advised her that she should not go along with that. 'You must be a good girl. You should be able to reject all bad things that initiated by your friends ' My child 
was very happy to go with me. She said, 'Mama is a kind and pleasant person. I love mama. "She said that she wanted to do that again with me." (AY, 40 years old)

At the 2oth session, the writer asked participants in Ciluar to write down the benefits theygotafterparticipating in learning activities at Mother School. Participants' answers were very varied, touching, and 30 participants agreed that Mother School program provided enormous benefits for their lives. Some of the participants' opinions are as follows:

"I got knowledge or lessons to overcome problems in my household. Honestly, before I attended Mother School, I had a conflict in my household that was difficult for me to resolve. Our selfishness was high. For 6 months my partner and I didn't speak to each other. Almost divorce. But after attending Mother School, I learned how to deal with the conflict. Alhamdulillah, now I live happily. Now there is more communication/mutual openness, and the divorce, Alhamdulillah, it didn't happen. "(H W, 40 years old)

"There are many benefits that I can get. I am more in control of my emotions. More "Istighfar". It could be a reminder for me. Alhamdulillah, the change was not only for me, but also for my husband and children. Especially my eldest son, on Tuesday after studying the Koran, he gave a letter in which he apologized to me and promised to change his ugly nature. Alhamdulillah, I feel so grateful."(NF, 29 years)

"Some benefits that I've got from participating in Mother School were that I become more patient and know better about being a mother; become more loving towards children and husband because at Mother School we were taught how to deal with/understand our husband and children who we really care about; and create better communication." (YW, 50 years old)

"I joined Mother School program so I gained more knowledge in caring for my family. Alhamdulillah, I don't easily get angry anymore. Families become more harmonious, and also quarrels in my family become less severe." (HS, 36 years old)

Written opinions from Mother School participants in Ciluar sub-district indicated that they really enjoy learning and engage in Mother School activities. The participants directly felt the benefits when educating their children and realized that the material provided at Mother School could improve communication among family members, strengthen husband-wife relationship as well as mother-child relationships, improve parenting and show how to educate children, and increase their knowledge related to motherhood.

The opinion also showed that marital satisfaction has positive impact on parenting pattern. Santrock (2007) revealed that marital relations are one of the important supporting factors in childcare. When a husband and wife feel happiness in their marriage, and can establish good communication and relationships, they tend to be more affective towards their children. Guanchen and Shijie (2013) believed that harmonious marriage guarantees good family harmony and good interpersonal relationships, so that people are expected to live in harmony.

Conversely, poor communication and interaction of husband and wife can lead to disharmony in the family which results in divorce. Research Prianto et al. (2013) found that length of courtship, marriage duration, and education level did not guarantee a person would avoid divorce. Divorce can occur at any time when the bond between the partners is not strong enough and there is a trigger that could detonate at any time. Moreover, currently most of the divorce lawsuits are filed by women. The existence of Mother School is expected to be able to realign the role of mothers in the family and strengthen family resilience, so as to reduce the divorce rate in Bogor City.

Communication erroronfamilymembers could have happened if the messenger was not clearly presented, with improper delivery method, lacking of consideration when to say something, and lacking of consideration to 
the condition of the other party. On the other hand, the recipient of the message can also cause communication errors. This happens when the recipient of the message was not open about the ideas of others, already had a certain view, and did not consider the condition or situation of the messenger (Setiono, 2011).

Gunarsa (2004) asserted that family harmony is a condition when all family members feel happy which is marked by reduced tension, disappointment, and increased feelings of satisfaction with all circumstances and their existence which includes physical, mental, and social aspects. This finding strengthens the results of Andjariah's (2005) study of 26 employees and lecturers at Yogyakarta Proklamasi 45 University, which concluded that there was a significant relationship between husband and wife communication with marital happiness. Positive family communication is expected to increase love, creativity, hope, and family happiness. In addition, family communication can also create conditions that facilitate the development of family potential, or use communication to create optimal conditions for growth and development.

One factor to build family resilience is the effort to shape the personality of family members with religious values and norms (Fadhli, 2012). Both of these things - inheritance of values and inculcation of religious norms - can be done well by parents if positive communications were established within the family. Therefore, each family member needs to master the correct way of communicating, so as to avoid communication errors.

\section{CONCLUSION}

Closeness and family togetherness is the keyin building family harmony. Many benefits were felt by the participants from Mother School program. One participant survived the household conflict that had lasted for 6 months and finally avoided divorce. After attending Mother School, participants felt stronger relationships with their husband and children. Mother School is considered as a facility that can increase knowledge and insight that can be applied directly in family life. Participants also expressed the way they communicate with their husbands and children that had become better, more patient and more able to control their emotions. Due to the busy schedule of parents and children nowadays, the time to communicate directly to each other becomes limited. Therefore, the author recommended that each family have daily routine activities together. Dinner and sports events on holidays, for example, can be used as routine activities so that all family members can gather and talk. If necessary, parents could make a deal with the children to temporarily stop the activity with the device while chatting. The findings of this particular study can largely contribute in developing family harmony in Indonesia, especially Bogor. In the future, Mother School is expected to be developed further into Family School (Sekolah Keluarga). Also, the program may require the involvement of husbands (fathers).

\section{ACKNOWLEDGEMENT}

The author would like to express sincere gratitude to the Chairman of the PKK (Family Welfare Development Program) Mobilization Team of Bogor City, Mrs. Yane Ardian Bima Arya, who gave the writer the opportunity to become a tutor at Mother School. During the teaching at Mother School, the writer gained a lot of valuable experiences. The author would also like to thank her fellow instructors, Ms. Lisna Sukaidawati, Ms. Retno Kumoro, Ms. Siti Nurlayla, and Ms. Irmalia Novianti , who helped the author distribute questionnaires in Ciparigi and Kedung Halang villages. Also, the author would like to thank Mrs. Eka Wulida Latifah who had assisted in processing the results of this research by using statistic programs. 


\section{REFERENCES}

Acharya, N. \& Joshi, S. (2009). Influence of parents' education on achievement motivation of adolescents. Indian Journal Social Science Researches, 6(1), 72-79.

Amalia, R.M., Akbar, M.Y.A., \& Syariful. (2017). Ketahanan keluarga dan kontribusinya bagi penanggulangan faktor terjadinya perceraian. Jurnal $A l$ Azhar Indonesia Seri Humaniora, 4(2), 129-135. http://dx.doi.org/10.36722/ sh.v4i2.268

Andjariah, S. (2005). Kebahagiaan perkawinan ditinjau dari faktor komunikasi pada pasangan suami istri. Jurnal Psikologi, 1(1), 1-5 .

Asilah \& Hastuti, D. (2014). Hubungan tingkat stres ibu dan pengasuhan penerimaanpenolakan dengan konsep diri remaja pada keluarga bercerai. Jurnal Ilmu Keluarga \& Konsumen, 7(1), 10-18. https://doi.org/10.24156/jikk.2014.7.1.10

Badan Pusat Statistik (BPS). (2018). Statistik Indonesia 2018. Jakarta: BPS.

e Silva, R.N.A., Bongardt, D.V.D., LooijJansen, P.V.D., Wijtzes, A., \&Raat, H. (2016). Mother- and father-adolescent relationships and early sexual intercourse. Pediatrics, 138(6), 1-9. https://doi.org/10.1542/peds.2016-0782

Fadhli, A. (2012). Membangun ketahanan keluarga melalui penguatan pondasi agama. Jurnal Momentum, 2(2), 53-64.

Goldberg, J.S., \& Carlson, M.J. (2014). Parents' relationship quality and children's behavior in stable married and cohabiting families. J Marriage Fam., 76(4), 762-777. https://doi.org/10.1111/ jomf.12120

Guanchen, S. \& Shijie, S. (2013). Constructing a Harmonious Family: Family Relationships From Estrangement to Interaction. CrossCultural Communication, 9(5), 82-86. http://dx.doi.org/10.3968/j. ccc.1923670020130905.2823
Gunarsa, S. D.\& Gunarsa, Y. (2004). Psikologi Praktis: Anak, Remaja dan Keluarga. Jakarta: BPK Gunung Mulia.

Hamzah, A. (2002). Pengaruh komunikasi keluarga terhadap kenakalan remaja. (Studi tentang kenakalan remaja di Kelurahan Karang Besuki Malang). [Thesis]. Universitas Negeri Malang, Malang.

h t t p s : / / w w w . i n d o p o s . co.id / $\mathrm{read} / 2018 / 09 / 22 / 150411 /$ ketika-tingkatperceraian-makin-tinggi-di-bogor. Downloaded on Rabu, 10 Oktober 2018.

Kementerian Pemberdayaan Perempuan dan Perlindungan Anak (KPPPA). (2016). Pembangunan Ketahanan Keluarga. Jakarta: KPPPA.

Koerner, A.F. \& Fitzpatrick, M.A. (2004). Communication in intact families. In A.L. Vangelisti (editor). Handbook of Family Communication. Mahwah, New Jersey: Lawrence Erlbaum Associates, Inc.

Mefalopulos, P. (2008). Development Communication Sourcebook. Broadening the Boundaries of Communication. Washington DC (US): The World Bank.

Megawangi, R. (2007). Pendidikan Karakter: Solusi yang Tepat untuk Membangun Bangsa. Jakarta: Indonesia Heritage Foundation.

Metia, C. (2017). Hubungan komunikasi interpersonal dengan keharmonisan keluarga pada ibu-ibu sebagai karyawan di kecamatan Percut Sei Tuan. Consilium, 4(4), 22-40.

Muhwezi, W.W., Katahoire, A.R., Banura, C., Mugooda, H., Kwesiga, D., Bastien, S., \& Klepp, K.I. (2015). Perceptions and experiences of adolescents, parents and school administrators regarding adolescent-parent communication on sexual and reproductivehealth issues in urban and rural Uganda. Reproductive Health, 12(110), 3-16. https://doi. org/10.1186/s12978-015-0099-3 
Nancy, M. N. (2013). Hubungan nilai dalam perkawinan dan pemaafan dengan keharmonisan keluarga. Proceeding Pesat (psikologi, ekonomi, sastra, arsitektur \& teknik sipil), 5, 32-39.

Pramono, F., Lubis, D.P., Puspitawati, H., \& Susanto, D. (2016). The influence of adolescent communication patterns to emotional intelligence and learning achievement of senior high school students in Bogor. International Journal of Sciences: Basic and Applied Research (IJSBAR), 30 (1), 121-134.

Prianto, B., Wulandari, N. W. \& Rahmawati, A. (2013). Rendahnya komitmen dalam perkawinan sebagai sebab perceraian. Jurnal komunitas, 5(2), 208-218.

Puspitawati, H. (2006). Pengaruh faktor keluarga, lingkungan teman dan sekolah terhadap kenakalan pelajar di Sekolah Lanjutan Tingkat Atas (SLTA) di Kota Bogor. [Dissertation]. Program Studi Gizi Masyarakat dan Ilmu Keluarga. Pascasarjana IPB. Bogor.

Puspitawati, H. (2012). Gender dan Keluarga. Konsep dan Realita di Indonesia. Bogor: IPB Press.

Rahmah, S. (2018). Pola komunikasi keluarga dalam pembentukan kepribadian anak, Jurnal Alhadharah, 17(33), 13-31. http://dx.doi.org/10.18592/alhadharah. v17i33.2369

Rahmawati \& Gazali, M. (2018). Pola komunikasi dalam keluarga. Al-Munzir, 11(2), 163-181.

Runcan, P. L., Constantineanu, C., Lelics, B., \& Popa, D. (2012). The role of communication in the parentchild interaction. Procedia - Social and Behavioral Sciences, 46, 904908. https://doi.org/10.1016/j. sbspro.2012.05.221

Santrock, J.W. (2007). Remaja. Jilid 2. Benedictine Widyasinta, translator. Jakarta: Penerbit Erlangga. Translated from: Adolescence. Ed ke-11.

Sari, D.P. \& Puspitawati, H. (2017). Family conflict and harmony of farmers family. Journal of Family Sciences, 2(1), 28-41. https://doi.org/10.29244/jfs.2.1.28\%20 $-\% 2041$

Segrin, C. \& Jeanne, F. (2005). Family Communication. Lawrence ErlbaumAssociates, United States of America (USA).

Setiono, K. (2011). Psikologi Keluarga. Bandung: Penerbit PT Alumni.

Socha, T.J. (2009). Family as Agency of Potential. In L.R. Frey dan K.N. Cissna (Eds). Routledge Handbook of Applied Communication Research (pp. 309330). New York (US): Routledge.

Song, I. S. \& Hattie, J. (1984). Home environment, self-concept, and academic achievement, A causal model in approach.Journal of Educational Psychology, 76 (6), 1269-1281. https:// doi.org/10.1037/0022-0663.76.6.1269

West, R. \& Turner, L.H. (2011). Pengantar Teori Komunikasi: Analisis dan Aplikasi. Buku 1. M.N.D. Maer, translator. Jakarta: Salemba Humanika. Translated from: Introducing Communication Theory: Analysis and Application. Ed. ke-3.

Wilson, G.L., Hantz, A.M., \& Hanna, M.S. (1995). Interpersonal Growth Through Communication. Iowa (US): WCB Brown \& Benchmark Publishers. Ed. ke-4.

Wiratri, A. (2018). Menilik ulang arti keluarga pada masyarakat Indonesia. Jurnal Kependudukan Indonesia, 13(1), 15-26. https://doi.org/10.14203/jki.v13i1.305 